\title{
External Morphological Features of the Gills of Ichthyophis bannanicus Embryo (Amphibia, Gymnophiona)
}

\author{
Características Morfológicas Externas de las Branquias del \\ Embrión de Ichthyophis bannanicus (Amphibia, Gymnophiona)
}

\author{
Shaoquan Meng,***; Yongjian Bei**; Guifen $\mathrm{Li}^{* * *}$; Ronghui Lu***; Baomin Qi"*** \& Defeng Wu ${ }^{* * * *}$
}

MENG, S.; BEI, Y.; LI, G.; LU, R.; QI, B. \& WU, D. External morphological features of the gills of Ichthyophis bannanicus embryo (Amphibia, Gymnophiona). Int. J. Morphol., 34(1):237-243, 2016.

SUMMARY: The gills of Ichthyophis bannanicus have yet to be investigated. This paper describes the external morphological features of the gills of mature I. bannanicus embryos exhibiting three pairs of gills on their neck region. Each gill is composed of an axis and filaments. In newly released embryos, the filaments and the axis form at approximately $90^{\circ}$ relative to each other; eventually, this angle decreases and the color of the gill fades. The filaments on the axis are arranged alternately, and their spacing varies. The mid-pair of gills is significantly longer by nearly twofold than the front and rear pairs. Likewise, the lengths of the front and rear pairs of gills are not significantly different $(\mathrm{P}>0.05)$; for the same pair of gills, the lengths of the left and right parts are not significantly different ( $\mathrm{P}$ $>0.05)$. The number of filaments is greater in the mid-pair of gills than in the front and rear pairs $(\mathrm{P}<0.05)$; the number of filaments in the front pair is not significantly different from that of the rear pair $(\mathrm{P}>0.05)$; the number of filaments in the left part does not significantly differ from that of the right parts $(\mathrm{P}>0.05)$. Results showed that the gills of $I$. bannanicus embryo are more similar to those of other species in Ichthyophiidae than to those of species in other families.

KEY WORDS: Amphibia; Caecilian; External gill; Morphology.

\section{INTRODUCTION}

The members of Gymnophiona, also known as cecilians, are difficult to observe because they live underground and because they exhibit nocturnal habits; thus, these animals are rarely known (Gower \& Wilkinson, 2005). Ichthyophis bannanicus is the only representative of Gymnophiona found in China (Fei et al., 2005). I. bannanicus belong to Ichthyophiidae, and the population of this species is relatively small and mainly distributed in Yunnan, Guangxi, and Guangdong in China (Ye et al., 1993; Wen, 1998). Ichthyophis larvae are aquatic; by contrast, Ichthyophis adults are terrestrial, and these adults particularly live in tunnels. Thus far, studies have focused on the embryonic gills of two caecilian divisions, namely, Caeciliidae, such as Gegeneophis carnosus (Ramaswami, 1954), and Ichthyophiidae, such as Ichthyophis bombayensis (Jadhav, 2010). However, the gills of I. bannanicus embryos have been rarely investigated; as such, the external morphological features of I. bannanicus remain unknown. Therefore, we investigated the morphological features of the gills of I. bannanicus embryos to provide useful baseline information for the subsequent studies on the development and physiology of the respiratory system of I. bannanicus.

\section{MATERIAL AND METHOD}

Materials. We found a clutch of 23 I. bannanicus eggs in the suburb of Beiliu in Guangxi, China, in our field work in July 2014. The clutch of eggs was washed by rain and partially exposed; the mother was still protecting the eggs. To prevent these eggs from being washed out or from being

\footnotetext{
College of Life Sciences, Fujian Agriculture and Forestry University, Fuzhou, Fujian, China.

** College of Life Science \& Technology, Yulin Normal University, Yulin, Guangxi, China.

${ }^{* * *}$ College of animal science, Fujian Agriculture and Forestry University, Fuzhou, Fujian, China.

This research was financially supported by the National Natural Science Foundation of China (Grant No. 31260509), the Program for Excellent Talents in Guangxi Higher Education Institutions (Grant No. 13-3), and the High-level Talents Scientific Research Starting Fund of Yulin Normal University (Grant No. G20130003).
} 
trampled upon, we placed, fed, and observed these eggs in a safe place. The clutch of eggs, along with the mother and a small amount of soil where these organisms were found, was brought to the laboratory and placed in a glass jar. On the second day, we collected six eggs while the mother was away from the eggs and used these eggs in other studies. On the fourteenth day, we collected eight eggs when the embryo matured to around stage 35 of the embryonic developmental stages of I. kohtaoensis (Dünker et al., 2000) to investigate the external morphological characteristics of the gills. The nine remaining eggs were hatched by the mother in the nest.

Observation and measurement of the external morphological features of gills. The eight eggs were rinsed with $0.7 \%$ saline to remove the attached sand and were placed in a Petri dish containing $0.7 \%$ saline solution; the short stem (Breckenridge \& Jayasinghe, 1979) of either end of the capsule was clamped with a tweezer, and the membrane was torn gently to release the embryo. The embryonic gills were observed and photographed; afterward, the embryos were placed in a paraformaldehyde-pentanedial fixative solution containing $4 \%$ formaldehyde and $2.5 \%$ pentanedial to fix the tissues for $24 \mathrm{~h}$ at $4{ }^{\circ} \mathrm{C}$; the gills were observed and photographed under a stereoscopic microscope (Nikon-SMZ800). The sizes (length and width) of the gills and filaments of the eight samples were measured using ImageJ. The length of the gills was measured from the base of the gills to the longest filaments of the tail; the width was obtained from the diameter of the base and the tail. The filaments were sampled from the base, the middle, and the tail of the axis; three samples were randomly obtained from the filaments extending forward and backward for measurement (six filaments in each part). The length of the filaments was measured from the base to the tip; the width of the filaments was obtained from the diameter of the base and the tail. The data obtained from the eight samples were analyzed using SPSS19.0.

\section{RESULTS}

Composition. The gills of $I$. bannanicus consist of three pairs: front, middle, and rear pairs; the gills are located on both sides of the neck (Figs. 1A and 1B). Each pair consists of the left and right gills. I. bannanicus possesses six gills, namely, left front gill (LF), right front gill (RF), left middle gill (LM), right middle gill (RM), left rear gill (LR), and right rear gill (RR). Each gill, which resembles a feather (Fig. 2), comprises an axis and filaments. An enlarged gill also resembles a ramus tree; hence, the gill is also called a ramus.
Color. The newly released gills were bright red; the gills initially appeared plump (Fig. 1A) and then gradually turned pale; the filament ends eventually folded (Fig. 1B). The entire gills turned white after approximately $20 \mathrm{~min}$.

Length of the gills. The length of the gills of the mid-pair is nearly twice the lengths of the front and the rear pairs. The front and rear pairs of gills were relatively short, and their lengths were not significantly different $(\mathrm{P}>0.05)$. Likewise, the length of the left and right gills of each pair was not significantly different $(\mathrm{P}>0.05$, Table I).

Gill axis. The gill axis refers to the middle axis of the gill; the axis base of the front and rear gills vertically grows from the lateral neck skin and then sharply stretches forward and backward. The axis base of the middle gill also vertically grows from the lateral neck skin and then sharply stretches backward (Figs. 1A and 1B). The gill axis bears many filaments. The diameter of the axis decreases from the base to the tail; at the end of the axis, one to two filaments grow (Figs. 1A, 1B and 2, Table I).

Number of filaments. The number of filaments of the different gill pairs vary; among these pairs, the middle pair contained the greatest number of filaments, and this result significantly differed from that of the front and rear pairs $(\mathrm{P}<0.05)$; by contrast, the number of filaments of the front pairs differed from that of the rear pairs, but this difference was not significant $(P>0.05)$. Likewise, the number of the filaments of the left and right gills of one pair did not significantly differ $(\mathrm{P}>0.05$, Table I).

Development of the filaments. In the newly released embryo, the filaments and the axis form nearly a right angle relative to each other (Fig. 1A); the angle gradually decreases to less than $50^{\circ}$ (Fig. 2). The filaments grow in alternating patterns on both sides of the gill axis, and few of these filaments grow in pair (Figs. 1A, 1B and 2). The distance between two adjacent filaments is uncertain; distance may be great or small; in some instances, filaments are tightly connected to each other (Fig. 2).

Size of the filaments. The filaments are mostly cylindrical except the relatively flat region connected to the axis. In an individual, the longest filament is commonly located in the middle axis of the mid-pair of the gills; by contrast, the shortest filaments are found in the tails of the three pairs. The length of the filaments at the base of the axis and in the middle part of the mid-pair of the gills did not significantly differ from that of the corresponding filaments in the front pair $(\mathrm{P}>0.05)$; conversely, the length of the filaments at the base of the axis and in the middle part of the mid-pair of the gills significantly differed from that of the corresponding filaments in the rear 
pair $(\mathrm{P}<0.05)$. The lengths of the filaments in the tails of the axis of the three pairs of gills did not significantly differ $(\mathrm{P}$ $>0.05$ ). Likewise, the lengths of the filaments in the corresponding parts of the axis of the left and right gills in a pair did not significantly differ $(\mathrm{P}>0.05$, Table II). In a gill, the length of the filaments in the middle axis was greater than that of the filaments in the base and in the tail; the length

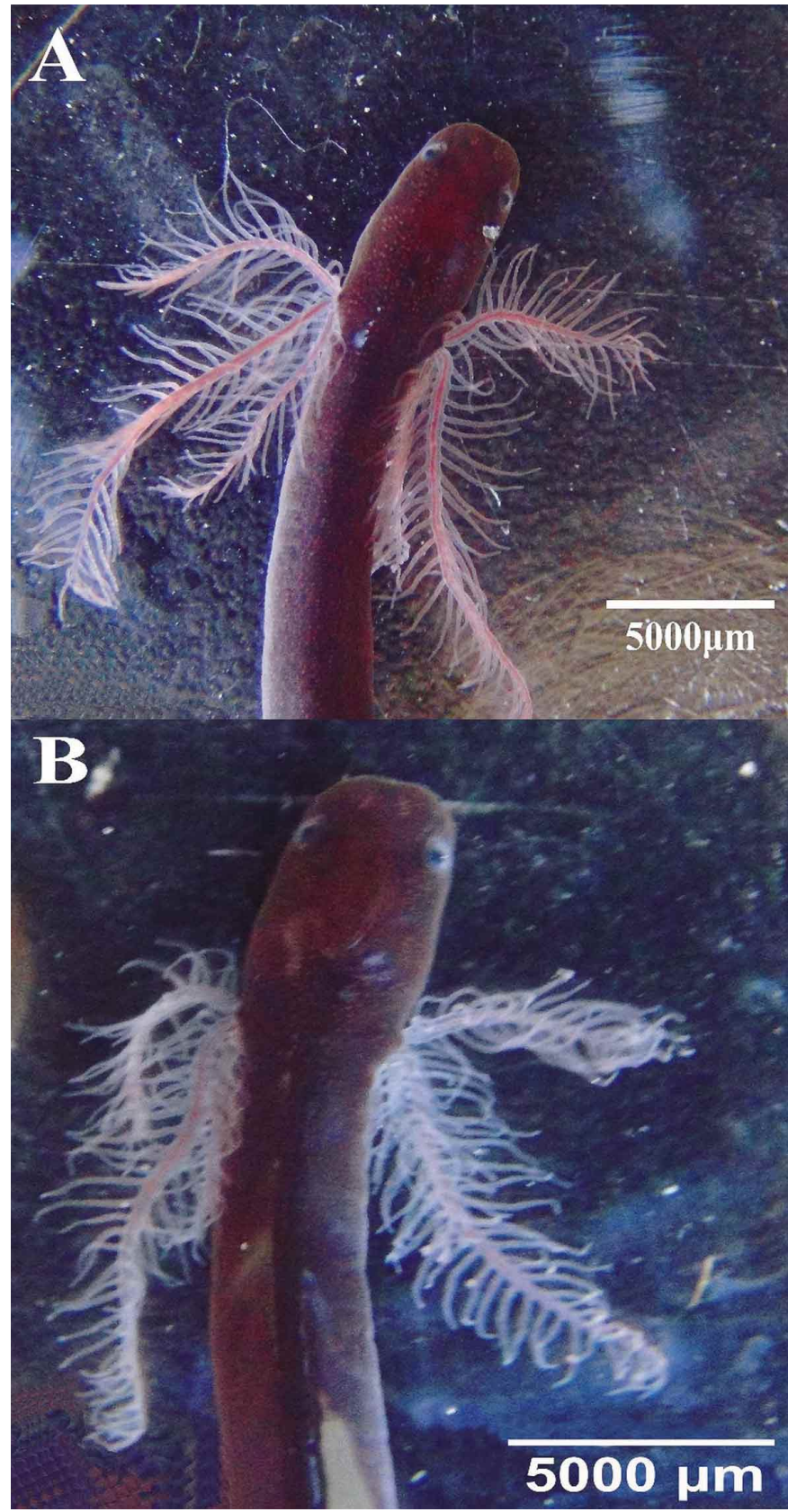

Fig. 1. A) Gill of a newly dissected mature embryo of I. bannanicus. The gills are engorged and scarlet, the filament nearly perpendicular to the axis; the gills growing vertically from the neck sides extend sharply forward or backward. B) Embryonic gill 20 min after removal from the egg capsule. The color faded, the filament crimped, and the angle was reduced. of the filaments in the middle axis did not significantly differ from that of the filaments in the base $(\mathrm{P}>0.05)$. By contrast, the length of the filaments in the middle axis significantly differed from that of the filaments in the tail $(\mathrm{P}<0.05$, Table II). The diameter of a filament decreased gradually from the base to the tail; in the tail, these filaments end with a fingerlike structure (Fig. 2).

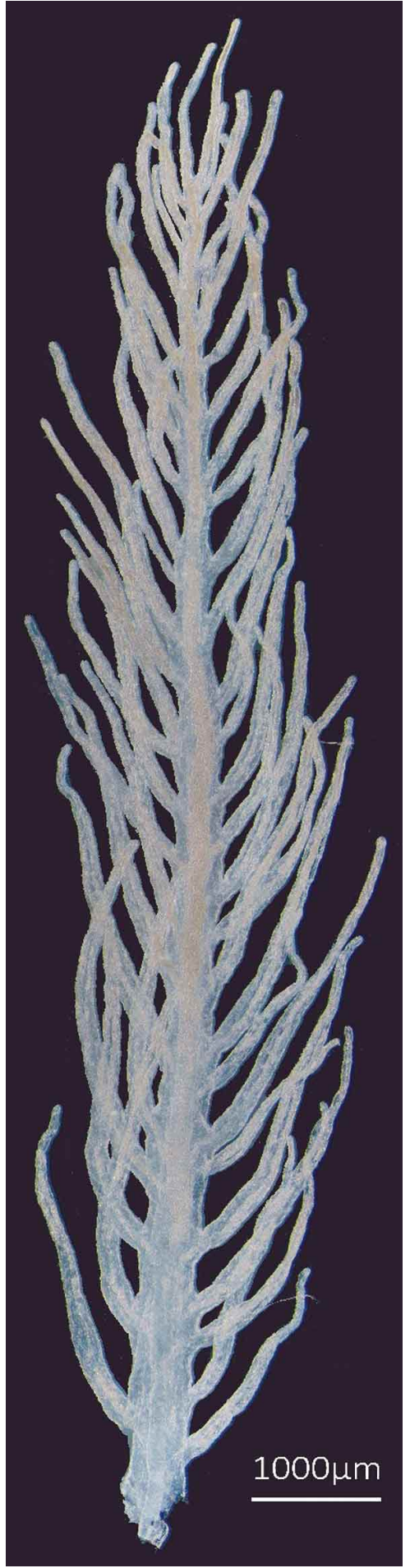

Fig. 2. Fixed LM gill of mature $I$. bannanicus embryo. The gill appeared like a white feather, the angle of inclination is small.

The filaments are mostly alternate and the spacing between filaments is varied, and the filaments form a finger-like shape. 
MENG, S.; BEI, Y.; LI, G.; LU, R.; QI, B. \& WU, D. External morphological features of the gills of Ichthyophis bannanicus embryo (Amphibia, Gymnophiona). Int. J. Morphol., 34(1):237-243, 2016.

Table I. Size of the gills of Ichthyophis bannanicus (Mean $\pm \mathrm{SD}, \mathrm{n}=8$ ).

\begin{tabular}{lcccc}
\hline & Length $(\boldsymbol{\mu m})$ & \multicolumn{2}{c}{ Breadth $(\boldsymbol{\mu m})$} & Number of filaments \\
& & Base & Tail-end & \\
\cline { 2 - 5 } LF & $6269.39 \pm 979.21 \mathrm{~b}$ & $442.75 \pm 22.57^{\mathrm{a}}$ & $117.37 \pm 17.88 \mathrm{a}$ & $35.33 \pm 3.78^{\mathrm{b}}$ \\
RF & $6359.35 \pm 1076.94^{\mathrm{b}}$ & $453.06 \pm 129.37 \mathrm{a}$ & $85.85 \pm 24.07 \mathrm{a}$ & $36.00 \pm 5.20^{\mathrm{b}}$ \\
LM & $10779.51 \pm 1223.83 \mathrm{a}$ & $455.69 \pm 49.22^{\mathrm{a}}$ & $99.27 \pm 57.34 \mathrm{a}$ & $68.33 \pm 5.69 \mathrm{a}$ \\
RM & $11788.86 \pm 1979.33 \mathrm{a}$ & $391.58 \pm 39.52^{\mathrm{a}}$ & $120.64 \pm 7.70 \mathrm{a}$ & $63.33 \pm 5.51 \mathrm{a}$ \\
LR & $6497.96 \pm 1164.78^{\mathrm{b}}$ & $250.84 \pm 28.74^{\mathrm{b}}$ & $95.61 \pm 11.00 \mathrm{a}$ & $42.00 \pm 4.58^{\mathrm{b}}$ \\
RR & $6547.06 \pm 837.10 \mathrm{~b}$ & $258.96 \pm 28.43^{\mathrm{b}}$ & $136.14 \pm 36.18 \mathrm{a}$ & $38.00 \pm 4.00^{\mathrm{b}}$ \\
\hline
\end{tabular}

Note: Multiple comparisons using LSD test. In each column, different lower case letters indicate significant difference between gills $(\mathrm{P}<0.05)$; identical lower case letters indicate no significant difference between gills $(\mathrm{P}>0.05)$. For abbreviations, see the Results.

Table II Length of the gill filaments $(\mu \mathrm{m})$ in different parts of the axis in each gill of Ichthyophis bannanicus $(\mathrm{Mean} \pm \mathrm{SD}, \mathrm{n}=48)$.

\begin{tabular}{lcccccc}
\hline & LF & RF & LM & RM & LR & RR \\
\cline { 2 - 7 } Base & $1693.26 \pm 642.78^{\mathrm{aA}}$ & $1993.52 \pm 440.02^{\mathrm{A}}$ & $1617.71 \pm 703.68^{\mathrm{aA}}$ & $1647.89 \pm 475.31^{\mathrm{bA}}$ & $1176.35 \pm 579.97^{\mathrm{aB}}$ & $1367.89 \pm 214.27^{\mathrm{aB}}$ \\
Middle & $1945.93 \pm 288.66^{\mathrm{aA}}$ & $1891.89 \pm 539.18^{\mathrm{A}}$ & $2115.84 \pm 519.74^{\mathrm{aA}}$ & $2235.95 \pm 597.82^{\mathrm{aA}}$ & $1545.66 \pm 251.56^{\mathrm{aB}}$ & $1586.27 \pm 311.31^{\mathrm{aB}}$ \\
Tail-end & $1093.24 \pm 163.47^{\mathrm{bA}}$ & $1171.23 \pm 281.74^{\mathrm{bA}}$ & $688.85 \pm 335.35^{\mathrm{bB}}$ & $1272.25 \pm 118.31^{\mathrm{bA}}$ & $1118.04 \pm 174.21^{\mathrm{aA}}$ & $1036.78 \pm 80.50^{\mathrm{bA}}$ \\
\hline
\end{tabular}

Note: Multiple comparisons using LSD test. Different lower case letters in the same column indicate significant difference $(\mathrm{P}<0.05)$ between gill filaments in different positions in the axis of a gill; identical lower case letters indicate no significant difference $(\mathrm{P}>0.05)$ between gill filaments in different positions in the axis of a gill; Different capital letters on the same row indicate significant difference $(\mathrm{P}<0.05)$ between gill filaments in the same gill axis positions in different gills; identical capital letters indicate no significant difference $(\mathrm{P}>0.05)$ between filaments in similar regions of different gill positions.

\section{DISCUSSION}

In a typical structure of gymnophiona gills, each caecilian embryo contains three gills in each head side except the gills of Typhlonectes (Peters, 1874, 1875; Parker, 1956; Taylor, 1968; Wake, 1969; Nussbaum \& Wilkinson, 1989; Wilkinson, 1989; Sammouri et al., 1990; Exbrayat \& HraouiBloquet, 1991, 1992; Hraoui-Bloquet \& Exbrayat, 1994; Wilkinson \& Nussbaum, 1997) and Chthonerpeton (Lieberman, 1939; Parker) with a huge sac-like gill on both sides of the head. However, Jadhav observed that the gills of I. bombayensis larvae grow in the sides of the neck; this finding is consistent with our observations, which showed that the three gills of I. bannanicus embryo grow on each side of the neck (Figs. 1A and 1B). Researchers found that the gills grow on both sides of the head; Jadhav and our group revealed that the gills grow on both sides of the neck. However, we have yet to determine the factor causing this difference. We assumed that this discrepancy is attributed to interspecific difference, but this possible reason remains uncertain because some images, Figures 2D, 2E, 2F, 3J, and $3 \mathrm{~K}$ (see in Dünker et al.) and Figures 5c, 5d, and 5e (see in Breckenridge \& Jayasinghe) of the gills of caecilian embryos or larvae in previous studies reveal that these gills grow on the sides of the neck rather than on the sides of the head.

The color of gills has rarely been described. Breckenridge and Jayasinghe observed that the embryonic gills in eggs are red; however, Breckenridge and Jayasinghe did not record the color of the gills of newly hatched larvae. Jadhav found that the gills of newly hatched I. bombayensis larvae appear bright red; after $15 \mathrm{~h}$ to $20 \mathrm{~h}$, the color of these gills fades. The gills then detach from the sides of the neck. The gills of I. bannanicus embryos are similar to those of $I$. bombayensis larvae in terms of color and color change; in particular, the gills are bright red for a particular period after the gills are removed from the egg capsules (Fig. 1A) and then gradually turn white after approximately $20 \mathrm{~min}$ (Fig. 1B).

In the mature phase of Caeciliidae embryos, the mid gills of Gymnnopis multiplicata are almost twice longer than the front and rear gills (Wake); by contrast, the mid gills of Hypogeophis rostratus are slightly longer than the front and rear gills (Brauer, 1899; Marcus, 1907). In Gegeneophis carnosus, the front and mid gills were nearly equal in length and were longer compared with the rear gills, which contained few filaments (Seshachar, 1942; Ramaswami). In Caecilia orientalis, the front and rear gills were larger compared with the mid gills (Pérez et al., 2009). Among these Caeciliidae species, the gills of their embryonic gills develop differently and their sizes vary, except $G$. multiplicata whose gills are similar to those of I. bannanicus. By contrast, the gills of the mature embryos or larvae of Ichthyophiidae are almost the same. Among these gills, the 
mid gills of I. bombayensis are the longest (12 mm), followed by the front gills $(6.7 \mathrm{~mm})$ and the rear gills $(5.3 \mathrm{~mm})$ (Jadhav).The morphological characteristics of I. glutinosus gills are similar to those of I. bombayensis; in particular, the mid gills are the longest $(12.5 \mathrm{~mm})$, followed by the front gills $(6.5 \mathrm{~mm})$ and the rear gills $(5 \mathrm{~mm})$ (Breckenridge \& Jayasinghe). In I. kohtaoensis, the mid gills (12.5 $\mathrm{mm}$ to $16.0 \mathrm{~mm}$ ) are twice longer than the front and rear gills (Dünker et al.). We observed that the morphological characteristics of I. bannanicus are similar to those in previous studies; in particular, the mid gills of I. bannanicus were nearly twice longer than the front and rear gills (Table I). Thus, the gills of the mature embryos or larvae of Ichthyophiidae caecilians did not exhibit significant interspecific variation. Conversely, the morphological characteristics of the gills of the mature embryo of Caeciliidae caecilians show significant interspecific variation. This finding is consistent with the conclusions presented by Dünker et al.; Dünker et al. concluded that Rhinatrematidae and Ichthyophiidae are basic groups of Gymnophiona, whereas Caeciliidae is a highly derived evolutionary branch.

Seshachar concluded that the rear pair of gills is the shortest among the gill pairs of the embryonic gills of Ichthyophiidae. However, we observed that the rear pair of the gills of the embryonic gills of I. bannanicus was slightly longer than the front pair; despite this finding, the difference was not significant $(\mathrm{P}>0.05)$. Furthermore, distribution of the length of the rear gills differed greatly among the individuals in a clutch (Table I). Our conclusions and those of previous studies may be affected by a small sample size because Caecilian species samples are not easily obtained. If the sample size is very small, such as one or two samples, conclusions may be inaccurate. Nevertheless, our findings are consistent with those of Brauer, Breckenridge \& Jayasinghe, and Dünker et al., that is, the differences in the lengths of the gills of I. glutinosus, I. kohtaoensis, and I. bannanicus are evident (Table I).

The axis, which is an important component of the gill, has been rarely described. For instance, Jadhav found that the axis is cylindrical with a broad base and gradually becomes smaller toward the tip; this description is widely accepted. However, on the basis of the quantity, size, shape, and manner of the development of the filaments, which are one of the most important parts of gills, we obtained results that differ from those of Breckenridge \& Jayasinghe, Dünker et al., and Jadhav. First, in terms of quantity, the number of the filaments in the axis was greater in the embryonic gills of I. bannanicus (Table I) than in the gills of I. glutinosus (see Table III in Breckenridge \& Jayasinghe); conversely, the number of the filaments in the axis of the embryonic gills of I. bannanicus was equal to that of I. kohtaoensis (see Table II in Dünker et al.). However, this comparison is inaccurate because the sample size used by Breckenridge $\&$ Jayasinghe is unknown. Although the sample size of Dünker et al., is 3, we have yet to determine whether the number of filaments in Table II (see in Dünker et al.) is obtained from the left or the right head side of the gills because the number of filaments in the left and right gills in a pair differs (Table I). For example, Dünker et al., provided Table II (see in Dünker et al.) and showed that the middle gills of a larval sample in the 25th stage contain 50 filaments; however, whether this figure refers to LM or RM gills is unknown. Second, the size is different; the size of the gill filaments is very complex because this parameter includes the size of the filaments in the same position on the axis of different gills and the size of the filaments in different positions on the axis of the same gills. Breckenridge \& Jayasinghe and Jadhav did not record the length of the gill filament; instead, Breckenridge \& Jayasinghe and Jadhav only described that the gill axis tapers from the base to the tip, and the filament on the axis shortened as this axis tapers. Furthermore, Dünker et al., stated that the number and length of filaments in the mid gills are greater than those of the front and rear gills. Breckenridge \& Jayasinghe and Jadhav described the size of the filaments on the same gills; conversely, Dünker et al., described the size of the filaments on different gills. The sizes of the filaments from the same position of different gills of I. glutinosus (Breckenridge \& Jayasinghe) and I. bombayensis (Jadhav) have not been provided. Likewise, the sizes of the filaments from different positions of the same gills of I. kohtaoensis (Dünker et al.) have not been specified. We found that the length of the filaments in one part of the axis of different gills differs; for example, LF or RF exhibited the longest filaments found in the base of the axis, followed by LM or RM, and the shortest was observed in LR or RR. The filaments in different parts of an axis of a gill varied in length. For example, in LM or RM, the filaments in the mid part of the axis were longer than those in the base and tip of the axis, although the filaments in the base were longer than those in the tip. Moreover, the differences in the length of the filaments in the tip of gills were not significantly different; in a gill, the filaments in the mid axis were longer than those in the base and tip (Table II). Third, in terms of shape, the filaments are cylindrical and as fine as silk in caecilian species, except for Typhlonectes and Chthonerpeton, which do not exhibit filaments. Breckenridge \& Jayasinghe reported that the tip of the filaments in I. glutinosus is expanded into a "knob-like" end. We also observed "knob-like" filament ends in I. bannanicus, although the "knob-like" filaments were less than that of the finger type. Careful examination revealed that finger-like end was the true appearance, whereas the spherical end was a false appearance, which was caused by the distortion of some filaments. Fourth, are 
the differences in manner of development. In I. kohtaoensis, the filaments were perpendicular to the axis (Dünker et al.), whereas in I. bannanicus, this condition was observed right after the removal of the embryo from the egg capsule and for a short period only. The filaments and axis of the newly released embryo were at approximately right angle relative to each other; about 20 min later, the angle slowly adjusted to less than $50^{\circ}$ (Fig. 2). The duration of angular adjustment coincided with the color change, suggesting that a certain association exist between the two. Possibly, adequate blood flow into the gills caused the orientational relationship between filament and axis and resulted in the bright red coloration of the gills; inadequate blood flow into the gills reduced the angle of inclination of the filaments and caused the gill to whiten. In terms of gill development, Dünker et $a l$., reported nearly uniform spaces in between filaments in I. kohtaoensis, whereas the size of spaces differed in $I$. bannanicus. In addition, the filaments in I. bannanicus mostly occur in the axis in alternate and rarely in opposite fashion (Fig. 2).

\section{ACKNOWLEDGMENTS}

The authors are grateful to Li Jianda, who contributed to the discovery of the research samples. We appreciate Prof. Shoukun Wang's generosity in providing measuring tools. This research was financially supported by the National Natural Science Foundation of China (Grant No. 31260509), the Program for Excellent Talents in Guangxi Higher Education Institutions (Grant No. 13-3), and the High-level Talents Scientific Research Starting Fund of Yulin Normal University (Grant No. G20130003).

MENG, S.; BEI, Y.; LI, G.; LU, R.; QI, B. \& WU, D. Características morfológicas externas de las branquias del embrión de Ichthyophis bannanicus (Amphibia, Gymnophiona). Int. J. Morphol., 34(1):237-243, 2016.

RESUMEN: Las branquias del Ichthyophis bannanicus aún no se han investigado. En este trabajo se describen las características morfológicas externas de las branquias de embriones maduros de I. bannanicus, que exhiben tres pares de branquias en la región del cuello. Cada branquia está compuesta de un eje y filamentos. En embriones recién liberados los filamentos y la forma del eje es de aproximadamente $90^{\circ}$ respecto a la otra; finalmente, este ángulo disminuye y el color de las branquias se desvanece. Los filamentos en el eje están dispuestos en forma alternada y su separación varía. La media de par de branquias es significativamente más larga, por casi el doble que los pares anterior y posterior. Del mismo modo, las longitudes de la parte delantera y posterior de pares de branquias no son significativamente diferentes ( $p>0,05)$; para el mismo par de branquias, las longitudes de las partes izquierda y derecha no son significativamente diferentes $(\mathrm{p}>0,05)$. El número de filamentos es mayor en el par medio de branquias, que en la parte delantera y posterior de pares $(\mathrm{p}<0,05)$; el número de filamentos en el par frontal no es significativamente diferente de la del par trasero $(\mathrm{p}>0,05)$; el número de filamentos en la parte izquierda no varía significativamente del de las partes derechas ( $p>0,05)$. Los resultados mostraron que las branquias del embrión de I. bannanicus son más similares a los de otras especies en Ichthyophiidae que de otras especies.

PALABRAS CLAVE: Anfibio; Caecilian; Branquia externa; Morfología.

\section{REFERENCES}

Brauer, A. Beiträge zur Kenntnis der Entwicklungsgeschichte und der Anatomie der Gymnophionen. Zool. Jahrb. Anat., 12:477$508,1899$.

Breckenridge, W. R. \& Jayasinghe, S. Observations on the eggs and larvae of Ichthyophis glutinosus. Ceylon J. Sci. (Biol. Sci.), 13(1-2):187-202, 1979.

Dünker, N.; Wake, M. H. \& Olson, W. M. Embryonic and larval development in the caecilian Ichthyophis kohtaoensis (Amphibia, gymnophiona): a staging table. J. Morphol., 243(1):3-34, 2000.

Exbrayat, J. M. \& Hraoui-Bloquet, S. Morphologie de l'épithélium branchial des embryons de Typhlonectes compressicaudus (Amphibien Gymnophione) etudié en microscopie électronique a balayage. Bull. Soc. Herp. Fr., 57:45-52, 1991.
Exbrayat, J. M. \& Hraoui-Bloquet, S. Evolution de la surface branchiale des embryons de Typhlonectes compressicaudus, Amphibien Gymnophione vivipare, au cours du developpement. Bull. Soc. Zool. Fr., 117:340, 1992.

Fei, L.; Ye, C. Y.; Huang, Y. Z.; Jiang, J. P. \& Xie, F. An Illustrated Key to Chinese Amphibians. Chongqing, Sichuan Publishing House of Science and Technology, 2005.

Gower, D. J. \& Wilkinson, M. Conservation biology of caecilian amphibians. Conserv. Biol., 19(1):45-55, 2005.

Hraoui-Bloquet, S.; Exbrayat, J. M. Développement des branchies chez les embryons de Typhlonectes compressicaudus, amphibien gymnophione vivipare. Ann. Sci. Nat. Zool. Biol. Anim., 15:33-46, 1994. 
Jadhav, B. V. Observations on external gills of juvenile of Ichthyophis bombayensis (Amphibia-Ichthyophiidae). J. Exp. Zool. India, 13(1):281-4, 2010.

Liebermann, J. Distribución geográfica de los cecilidos argentinos. Physis (B. Aires), 26(48):83-8, 1939.

Marcus, H. Beiträge zur Kenntnis der Gymnophionen. I. Über das Schlundspaltengebiet. Arch. Mikrosk. Anat., 71:695-774, 1907.

Nussbaum, R. A. \& Wilkinson, M. On the classification and phylogeny of caecilians (Amphibia: Gymnophiona), a critical review. Herpetol. Monogr., 3:1-42, 1989.

Parker, H. W. Viviparous caecilians and amphibian phylogeny. Nature, 178:250-2, 1956.

Pérez, O. D.; Lai, N. B.; Buckley, D.; del Pino, E. M. \& Wake, M. H. The morphology of prehatching embryos of Caecilia orientalis (Amphibia: Gymnophiona: Caeciliidae). J. Morphol., 270(12):1492-502, 2009.

Peters, W. Über die Entwicklung der Caecilien und besonders der Caecilia compressicauda. Berlin, Monatsberichte der Akademie der Wissenschaften zu Berlin, 1874. pp.45-9.

Peters, W. Über die Entwicklung der Caecilien. Berlin, Monatsberichte der Akademie der Wissenschaften zu Berlin, 1875. pp.483-6.

Ramaswami, L. S. The external gills of Gegenophis embryos. Anat. Anz., 101(10-12):120-2, 1954.

Sammouri, R.; Renous, S.; Exbrayat, J. M. \& Lescure, J. Développement embryonnaire de Typhlonectes compressicaudus (Amphibia, Gymnophiona). Ann. Sci. Nat. Zool. Biol. Anim., 11:135-63, 1990.

Seshachar, B. R. The eggs and embryos of Geganophis carnosus Bedd. Curr. Sci., 11(11):439-41, 1942.

Taylor, E. H. The Caecilians of the World. A Taxonomic Review. Lawrence, University of Kansas Press, 1968. pp. 848.

Wake, M. H. Gill ontogeny in embryos of Gymnopis (Amphibia: Gymnophiona). Copeia (1):183-4, 1969.

Wen, Y. The current status of Ichthyophis bannanicus Yang. Sichuan J. Zool., 17(2):54, 1998.

Wilkinson, M. On the status of Nectocaecilia fasciata Taylor, with a discussion of the phylogeny of the Typhlonectidae (Amphibia: Gymnophiona). Herpetologica, 45:23-36, 1989.

Wilkinson, M. \& Nussbaum, R. A. Comparative morphology and evolution of the lungless caecilian Atretochoana eiselti (Taylor) (Amphibia: Gymnophiona: Typhlonectidae). Biol. J. Linn. Soc., 62(1):39-109, 1997
Ye, C.; Fei, L. \& Hu, S. Rare and Economic Amphibians of China. Chengdu, Sichuan Publishing House of Science and Technology, 1993. pp.19-20.

\author{
Correspondence to: \\ Wu Defeng \\ Qi Baomin \\ College of Animal Science \\ Fujian Agriculture and Forestry University \\ Jinshan \\ Fuzhou 350002 \\ Fujian
}

CHINA

Email: zj99289@yeah.net qbm64@163.com

Received: 07-08-2015

Accepted: 19-10-2015 